${ }^{1}$ Kvenvolden, K. A., Lawless, J., Pering, K., Peterson, E., Flores, J., Ponnamperuma, C., Kaplan, I. R., and Moore, C., Nature, 228, 923 (1970).

${ }^{2}$ Kvenvolden, K. A., Lawless, J. G., and Ponnamperuma, C., Proc, natn. Acad. Sci. U.S.A., 68, 486 (1971).

${ }^{3}$ Cronin, J. R., and Moore, C. B., Science, N.Y., 172, 1327 (1971).

4 Oró, J., Nakaparksin, S., Lichtenstein, H., and Gil-Av., E., Nature, 230, 107 (1971).

5 Oró, J., Gilbert, J., Lichtenstein, H., Wikstrom, S., and Flory, D. A., Nature, 230, 105 (1971).

${ }^{6}$ Lawless, J. G., Kvenvolden, K. A., Peterson, E., Ponnamperuma, C., and Moore, C., Science, N.Y., 173, 626 (1971).

7 Pering, K., and Ponnamperuma, C., Science, N.Y., 173, 237 (1971).

8 Atlas of Spectral Data and Physical Constants for Organic Compounds (edit. by Grasselli, J. R.) (CRC Press, Cleveland, Ohio, 1973).

9 Happ, G. P., and Stewart, D. W., J. Am. chem. Soc., 74, 4404 (1952).

10 Budzikiewicz, N., Djerassi, C., and Williams, D. H., Mass Spectrometry of Organic Compounds (Holden-Day, San Francisco, 1967).

11 Hrivnak, J., Sojak, L., Beska, E., and Janak, J., J. Chromatogr., 68, 55 (1972).

12 Meinschein, W. G., Space Sci. Rev., 2, 653 (1963).

13 Nagy, G., and Bitz, M. C., Arch. Biochem. Biophys., 101, 240 (1963).

14 Hayes, J. M., Geochim. cosmochim. Acta, 31, 1395 (1967).

15 Fatty Acids (edit. by Markley, K. S.), part 1 (Interscience, New York, 1960).

16 Miller, S. L., J. Am. chem. Soc., 77, 2351 (1955).

${ }^{17}$ Eck, R. V., Lippincott, E. R., Dayhoff, M. O., and Pratt, Y. T., Science, N.Y., 153, 628 (1966).

18 Allen, W. V., and Ponnamperuma, C., Currents in Modern Biol., 1, 24 (1967)

\section{Pleistocene Human Occupation and Extinct Fauna in Cloggs Cave, Buchan, South-east Australia}

A STRATIFIED and undisturbed occupation deposit containing stone and bone tools and a rich faunal assemblage has been discovered in a limestone cave at Buchan, in eastern Victoria (latitude $37^{\circ} 31^{\prime} \mathrm{S}$, longitude $148^{\circ} 10^{\prime} \mathrm{E}$ ). This is the first Pleistocene occupation site in which bone is preserved, yet found in eastern Australia.

Part of the deposit has been excavated, to a depth of $2 \mathrm{~m}$, where massive slabs of rock fall were encountered. The lowest level excavated yielded extinct fauna, including a mandible in situ of the extinct giant kangaroo, Sthenurus orientalis. Immediately above the horizon containing extinct fauna were traces of human occupation, in the form of stone tools. Charcoal associated with the lowest tools was dated to $17,720 \pm 840 \mathrm{BP}$ (ANU-1044).

The tool assemblage compares very closely with that of the 8,000 yr-old levels of the Rocky Cape cave in northern Tasmania, excavated by Jones ${ }^{1}$. Both assemblages comprise pebble tools, steep-edged scrapers and bone awls, all of which reflect the manufacture of skin rugs and of wooden implements such as spears.

The Buchan cave was apparently vacated about $8,000 \mathrm{yr}$ ago, a date of $8,720 \pm 230$ BP (ANU-1001) having been obtained on charcoal from a hearth level only $15 \mathrm{~cm}$ below the present floor of the cave. The rock shelter outside the cave was utilised, however, in more recent times.

The vacation of the dark, but warm and dry, inner cave may have occurred in response to the climatic amelioration at the end of the Glacial Period, but the faunal evidence shows that there was a basic climatic and vegetational stability over the period represented by the cave deposit, that is, from before 18,000 BP to 8,000 BP. The species represented inhabit grassland, open woodiand and dry sclerophyll forest habitats, together with wet grassy hollows and swampy alluvial flats such as are found along the Buchan River today.

Flotation techniques were used in processing the cave deposit, and by this means some vegetable material such as leaves and wood was recovered. Copralites were also found, and it has been possible to identify the species of grass eaten by the herbivores found at the site.

Work on Cloggs Cave thus has important implications for the study of the palaeoenvironment as well as for the prehistory of Australia, and is continuing under the aegis of the Australian Institute of Aboriginal Studies.

JoSEPHINE Flood

Department of Prehistory,

Research School of Pacific Studies,

Australian National University, Box 4, PO,

Canberra, ACT 2600

Received November 5, 1973.

1 Jones, R., Archaeol. phys. Anthrop. Oceania, 3, 186 (1968).

\section{BIOLOGICAL SCIENCES}

\section{Translation of Collagen mRNA from Chick Embryo Calvaria in a Cell-free System derived from Krebs II Ascites Cells}

Collagen is a helical molecule composed of three polypeptide chains ( $\alpha$ chains) each with a molecular weight of approximately 95,000 . The polypeptides are synthesised separately as precursor chains containing additional amino acids at the $\mathrm{NH}_{2}$ terminal end ${ }^{1-9}$. These pro $\alpha$ chains aggregate to form procollagen which is then secreted from the cell ${ }^{3,10}$. Procollagen peptidase removes the $\mathbf{N H}_{2}$ terminal segment from the soluble procollagen and the collagen is then deposited in extracellular fibres ${ }^{11}$.

Although there have been several recent reports of cellfree synthesis of collagen, these describe the continuation of collagen synthesis on pre-existing polysomes using disrupted cells from embryonic chick wings and legs ${ }^{6,7}$ and from L-929 fibroblasts ${ }^{22}$. We describe here the preparation of mRNA from 15-d chick embryo calvaria, and its translation in a true heterologous system derived from preincubated Krebs II ascites cells. Unlike previous reports, our system depends on the addition of exogenous RNA for protein synthesis.

The level of functional mRNA in the total RNA extracted from the calvaria was determined by its ability to direct the incorporation of radioactive proline into trichloroacetic acid (TCA)-tannic acid-precipitable material in a cell-free system derived from preincubated Krebs II ascites cell extracts. Components of the cell-free system are listed in Table 1. Proline incorporation had a magnesium optimum of $3 \mathrm{mM}$ and a broad potassium optimum with a peak at $55 \mathrm{mM}$. As has been previously noted ${ }^{13}$, low concentrations of EDTA stimulated incorporation. Ascorbic acid increased incorporation by $10 \%$ and was included routinely in the reaction mixture.

In a standard reaction, proline incorporation was linear for 30 to $40 \mathrm{~min}$ and gradually reached a plateau so that at $60 \mathrm{~min}$ the incorporation was $50-100$ times greater than background (without added mRNA). The extent of incorporation was directly proportional to the amount of calvaria RNA added to the reaction mixture. We were unable to saturate the system with the calvaria RNA under the assay conditions used.

The Krebs II ascites system was developed by Kerr et al. ${ }^{14,15}$ and Mathews and Korner ${ }^{16}$. While they found that protein synthesis in the ascites system was independent 